University of Nebraska - Lincoln

DigitalCommons@University of Nebraska - Lincoln

Library Philosophy and Practice (e-journal)

Libraries at University of Nebraska-Lincoln

August 2020

\title{
Effect of Social Media Addiction on Reading Culture: A Study of Nigerian Students
}

\author{
Isaac E. Anyira \\ Delta State Polytechnic Ogwashi-Uku, Nigeria, anyiraisaac@gmail.com \\ OBIORA KINGSLEY UDEM \\ Nnamdi Azikiwe University Awka Nigeria, ok.udem@unizik.edu.ng
}

Follow this and additional works at: https://digitalcommons.unl.edu/libphilprac

Part of the Library and Information Science Commons, and the Science and Technology Studies Commons

Anyira, Isaac E. and UDEM, OBIORA KINGSLEY, "Effect of Social Media Addiction on Reading Culture: A Study of Nigerian Students" (2020). Library Philosophy and Practice (e-journal). 4170.

https://digitalcommons.unl.edu/libphilprac/4170 


\section{Introduction}

Addiction is a psychological and physical inability to stop engaging in an activity, or substance, even though it is causing psychological and physical harm. It is a condition in which one who is addicted could no longer have control over an activity at the expense of more gainful or harmless activity. A person is said to be addicted when he/she becomes dependent on an activity as a lifestyle. Oftentimes, an activity in which one is addicted to is a potential threat to other activities which are more gainful. In this case, social media addiction among students is a potential threat to reading culture in Nigeria. Collins and Cheek (1999) defined reading as a process that requires the use of complex thought processes to interpret printed symbols as meaningful units and comprehend them as a thought unit in order to understand a printed message. Rubin (2002) referred to it as a total integrative process that includes the affective, perceptual, and cognitive domains in making sense of what is written. It is through reading that humans have the tools to transmit knowledge to each succeeding generation. In developed countries of the world, it is generally believed that readers are leaders. Reading, whether for therapeutic purposes, whether for aesthetics, for personal self-development, to up-date knowledge or keep abreast of developments or for academic purpose, is therefore an essential habit that forms the bedrock of greatness in everyone, regardless of age, gender or status. The Holy Bible clearly provides an evidence of the importance of reading for self-discovery in the case of Jesus Christ as indicated in the Gospel of St. Luke chapter 4 verses 16-19. It reads:

"16 And he came to Nazareth, where he had been brought up: and, as his custom was, he went into the synagogue on the Sabbath day, and stood up for to read. 17 And there was delivered unto him the book of the prophet Esaias. And when he had opened the book, he found the place where it was written, 18 The Spirit of the Lord is upon me, because he hath anointed me to preach the gospel to the poor; he hath sent me to heal the brokenhearted, to preach deliverance to the captives, and recovering of sight to the blind, to set at liberty them that are bruised, 19 To preach the acceptable year of the Lord. 20 And he closed the book, and he gave it again to the minister, and sat down. And the eyes of all them that were in the synagogue were fastened on him”. 
The above Scriptures noted that reading was the "Custom" of Jesus Christ. This is the passage where Jesus Christ discovered his mission on earth as written by Prophet Isaiah. There is no doubt that reading has so many benefits such as motivation and inspiration, inner peace and tranquility, prevents cognitive decline, aids sleep, lengthens lifespan, bypass TV, entertainment, better writing skills, improved focus and concentration, stronger analytical thinking skills, memory improvement, vocabulary expansion, improved knowledge, reduces stress, mental stimulation etc.

In spite of these numerous benefits, reading culture among students in Nigeria is on the decline (Ahmed, 2019). It is common knowledge that a good number of higher institution students have completely lost interest in reading. Faculty members across departments oftentimes lament the outbreak of poor reading habits among their students. Many of these students do not write in class as they are not interested in reading them later. That flair for reading among students is fast fading in an alarming rate. The consequences of poor reading culture include poor academic performance, examination malpractice, mass failure, anti-social behaviours, poor understanding, fear and anxiety towards examinations and tests, poor execution of research projects and assignments, fall in the standard of education among others.

It is worrisome to note that Nigeria has been rated by the World Culture Score Index as one of the countries in the world with the lowest reading culture. Available statistics from National Commission for Mass Literacy, Adult and Non-Formal Education show that 38 per cent of Nigerians are non-literate as four in 10 primary school children cannot read for comprehension. Regrettably, this adverse development is an ominous challenge the country seems not to be paying the needed attention (Akinfenwa, 2019). Poor reading culture is one of the most critical factors posing a threat to the development of education in Nigeria currently.

\section{Classes of Social Media}

There are different classes of social media networks which students engage. They include

1. Social networks: Facebook, Twitter, WhatsApp, Linkedin

2. Media sharing networks: Instagram, Snapchat, Youtube 
3. Discussion forums: Reddit, Quora, Digg

4. Bookmarking \& content curation networks: Pinterest, Flipboard

5. Consumer review networks: Yelp, Zomato, Tripadvisor

6. Blogging \& publishing networks: Wordpress, Tumblr, Medium

7. Social shopping networks: Polyvore, Etsy, Fancy

\section{Statement of Problem}

The rich literacy history the country is famous for is gradually becoming a thing of the past. In time past, the country had the best set of scholars and think-tank in Africa. Then, reading was an innate affection for both young and old. Students spend their days in the library. Students observe vigil reading. This was called "Awoko" because you have to remain awake all through the night reading. This reading inclination reflected so much on the quality of research output, leadership and civil discipline that brought pride to Nigerians anywhere in the world. This is no longer the case. There is widespread poor reading culture in Nigeria at the moment. Stakeholders in education sector have attributed the drop in reading culture in Nigeria to the lack of adequate awareness on its importance, inadequate library facilities, poor access to books and other reading materials, and growth in television viewership culture. Also, the introduction of the Global System of Mobile Communication (GSM) in Nigeria has been viewed as one progress that has come with certain negative tendencies that are detrimental to the culture of reading in the country. As if these weren't enough, the social media, which are accessible via numerous devices

including the mobile phone, have brought another dimension to the already bad situation. Ahmed (2019) stated that social media have contributed to the decline of reading culture among students because instead of using it positively, they use it to chat and spend most of their time doing that. Many of these students no longer have control over their use of these applications. A recent study reported that social media distract students from reading their books in the sense that they always use most of their time chatting or listening to music or watching videos (Ahmed, 2019). This is the tendency for social media addiction. This study therefore seeks to investigate how addiction to social media is contributing to poor reading culture among Nigeria students. 


\section{Objectives of the study}

1. To examine the social media used by Nigerian students, and how often they use them.

2. To identify the devices being used to access social media and the purpose of social media use.

3. To examine their frequency of reading and their purpose of reading.

4. To investigate their frequency of visiting the library to read or borrow books.

5. To identify the activities that students engage in during Covid-19 Lockdown.

6. To examine the extent to which social media negatively affect students' reading habits.

\section{Research Questions}

1. Which social media are used by Nigerian students, and how often do they use it?

2. What devices are used to access social media and for what purpose?

3. How often do Nigerian students read books, and what is their purpose of reading?

4. How often do they visit library to read or borrow books?

5. What are the activities that students engage in during Covid-19 Lockdown and which activity gave them more satisfaction?

6. To what extent do social media negatively affect students' reading habits?

\section{Literature Review}

Cultivating a reading culture is important to any individual and to the development of any nation. The declining interest in reading among youths today is a cause for alarm and a challenge to all (Mefor, 2011).The importance of reading in a nation's development cannot be overlooked. According to a former Nigerian Minister of Education, Prof. Ruqayyatu Ahmed Rufa'I, no country can dream of meaningful development if its citizens cannot read. She also stated that an enlightened citizenry can readily be mobilized for the attainment of political, social and economic goals of a nation. She however, lamented the poor state of readership culture among Nigerian youths (Rufa'I, 2011). According to Adesanya (2018) experience and available research works had shown that Nigerian students have poor attitudes toward reading. Adesanya 
who is a lecturer reported that the poor reading culture can be linked to the environment students find themselves and the impact of the social media on them. To him, Social media has taken over the reading of relevant learning materials in most schools, as students now spend more of their time on informal activities on the social media than on books. He further mentioned lack of well graded relevant reading materials and poorly equipped libraries as some of the factors inhibiting the promotion of the reading culture among students. Again, Adesanya stated that poor teaching methodology and lack of commitment from the teachers and parents were some of the collaborative factors aiding the negative habit. Moreover, Ogboko (2018) described the attitude of students toward reading as lukewarm, lazy and not encouraging. He added that social media has diverted the interests of students from reading because instead of them to use the medium for research purposes that will enhance their academic performance, they now use it for social purpose.

Emphatically, Johnson (1999) observed that the level of readership is to a large extent, an index to a country's level of development. Johnson inferred that a country's readership culture is proportional to the number of citizens who do effective reading in relation to the population of that particular country. Based on Johnson's inference, Nigeria is a poor readership culture because, those who are not actively reading, outnumber those who are actively reading. Johnson (1999) further stated that the inability to read by a large proportion of the population of a country points to under-development since reading, writing, and arithmetic constitute the foundation of elementary education. Furthermore, Iheanacho (2007) noted that a healthy reading culture has a pivotal role to play in the social, economic and technological development of any country. Reading is a very essential commodity in the task of nation building. It is a main political weapon in the development of any nation. Development countries of the world were able to attain that height because, at a point in their history, they were able to give themselves too much reading and research. Countries like Japan, America, and Britain etc. took to reading and research to achieve technological breakthroughs (Iheanacho, 2007). Most developing countries do not have a healthy reading culture hence they lack substantial information that could be utilized for national development (Fabunmi, and Folorunso, 2010).

It is necessary to sustain a reading culture otherwise literacy could revert to illiteracy. Those reasons inform the several readership promotion campaigns embarked upon by different 
organizations and individuals in Nigeria. For instance, Akinfenwa (2019) noted that the National Library of Nigeria had at various times embarked on the readership promotion campaign because it was committed to fostering the growth of development of knowledge and also deepen the experience and the enhancement of skills in the country by making the recorded knowledge freely available to readers. Also, the Lagos State government has been making huge attempts to revitalize reading culture, especially among the younger ones. The state government made the annual World Literacy Day one of the most celebrated in the state's official calendar. Also, through the Lagos State Parks and Gardens Agency (LASPARK) the state government has established libraries in almost all the state owned parks, availing users the immense opportunity to read while having fun. To further improve reading culture and empower children through books, government introduced a reading club in its parks where students meet with Nigerian authors on a regular basis to read to them and improve their reading skills (Akinfenwa, 2019).

Furthermore, Akinfenwa (2019) emphasized that the interest expressed by private institutions in trying to keep reading and literacy alive is commendable. Over the last decade, a number of literary prizes have helped in supporting Nigeria’s literary circles.

Similarly, The 9Mobile Prize for Literature, backed by the telecommunication company, the Nigeria Prize for Literature, sponsored by the NLNG Gas Company and the Miles Morland Grant, which supports authors working on a novel for a year are among some of the clear-cut interventions aimed at improving reading culture in the country (Akinfenwa, 2019).

\section{Materials and Methods}

The survey method was used for the study. An online survey was sent to 1500 students of higher institutions in Nigeria during the Lockdown necessitated by the outbreak of the dreaded Corona Virus (Covid-19) Pandemic. A total of 1300 questionnaire were completed and returned. This implies $86.7 \%$ return rate. Data was analyzed using graphical charts. 


\section{Data Analysis and Results}

The first chart addressed the social media type that the students make use of:

Chart 1: "Which of the following social media do you use?"

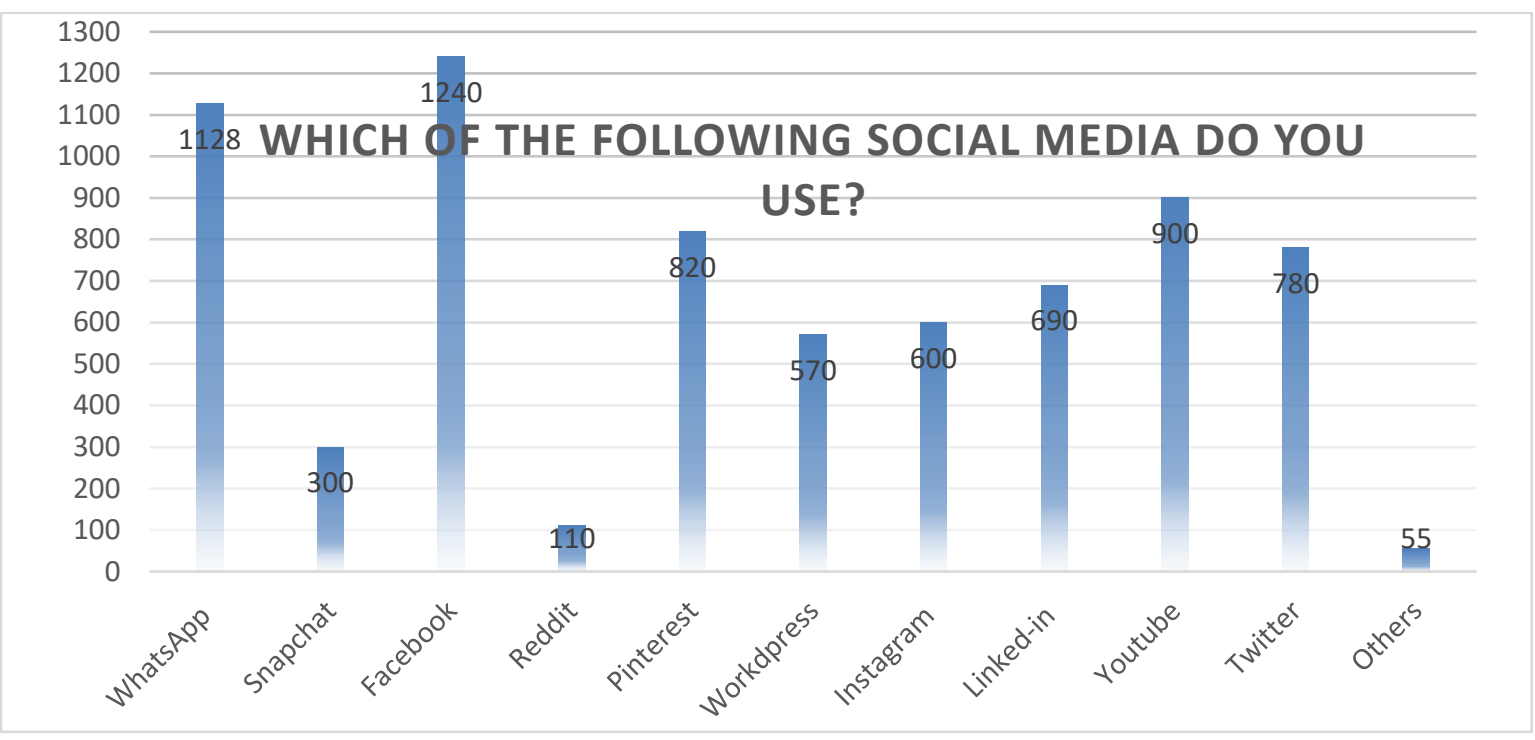

Respondents were at liberty to indicate as many social media as they make use of. The responses received indicate that1,240 of the 1300 (95.3\%) use Facebook followed by WhatsApp, with 1,128 (87\%). Other social media responded to include YouTube 900, Pinterest 820, Twitter 780, Linked-In 690, Instagram 600, Wordpress 570, Snapchat 300, Reddit 110, 55 indicated others. 
The second chart addressed the intervals of social media use:

Chart 2: "How often do you use social media?"

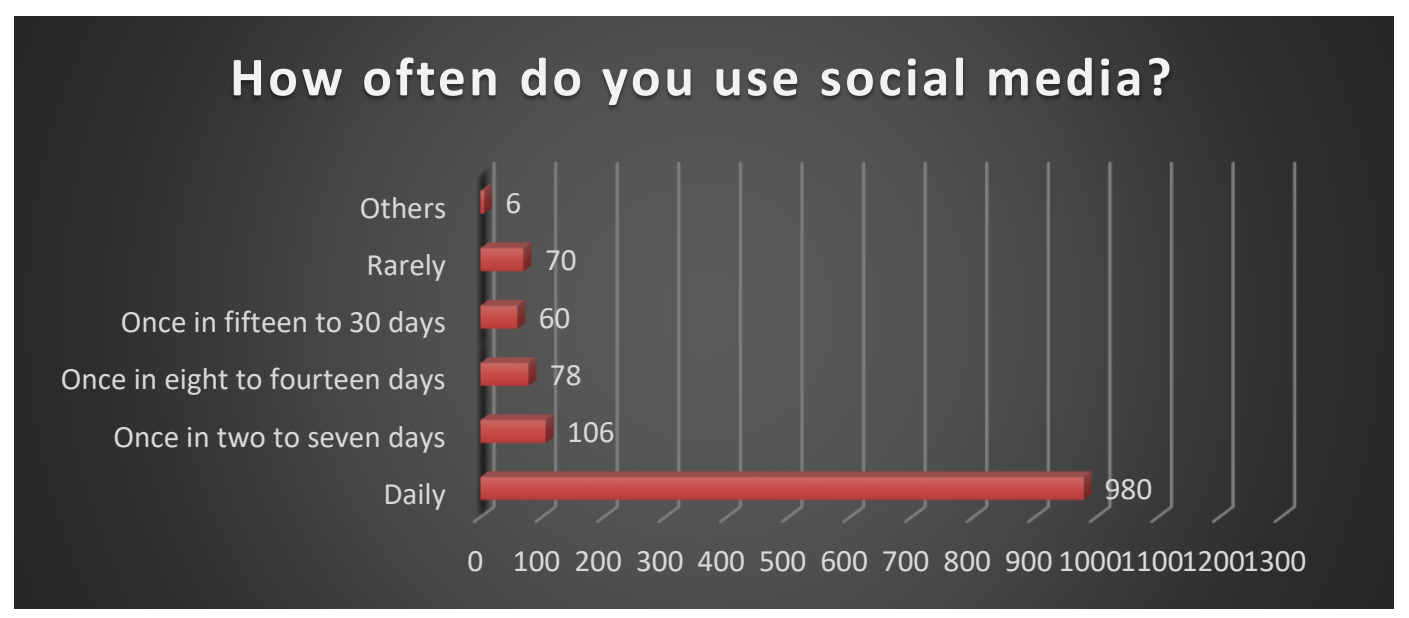

A total of 1300 responses were received, $980(75.3 \%)$ of them indicate they use the social media daily.106 of them use it once in two to seven days.

The third chart addressed the type of device(s) that are used to access social media:

Chart 3: "Which device(s) do you use to access social media?"

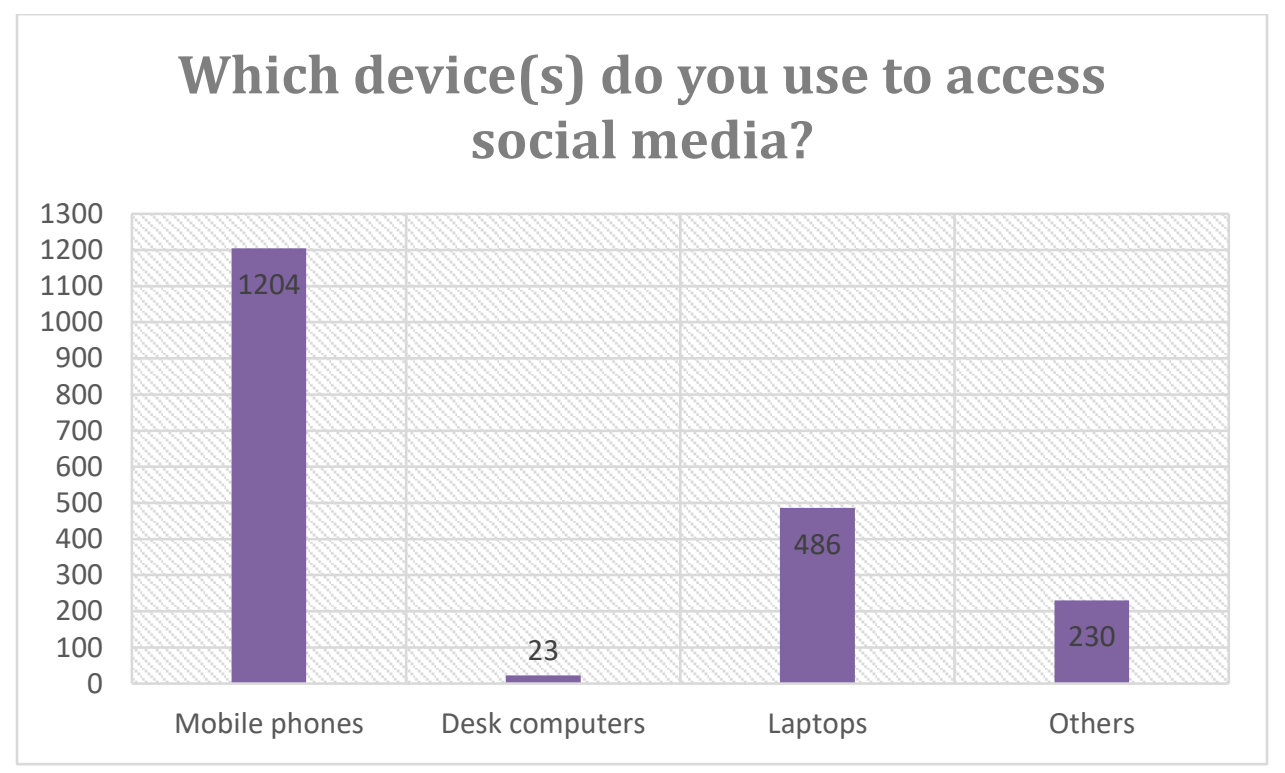


Respondents were at liberty to indicate multiple options relating to the devices that they use to access social media. The responses received indicate that1,200 of the 1300 (92.3\%) access the social media via their mobile phones. $486(37.3 \%)$ access social media through their Laptop computers, 23 (1.8\%) through desktop computers, and 230 (17.7\%) used other devices.

The fourth chart dealt with the reason for using social media:

Chart 4: "What are your main reasons for using social media?"

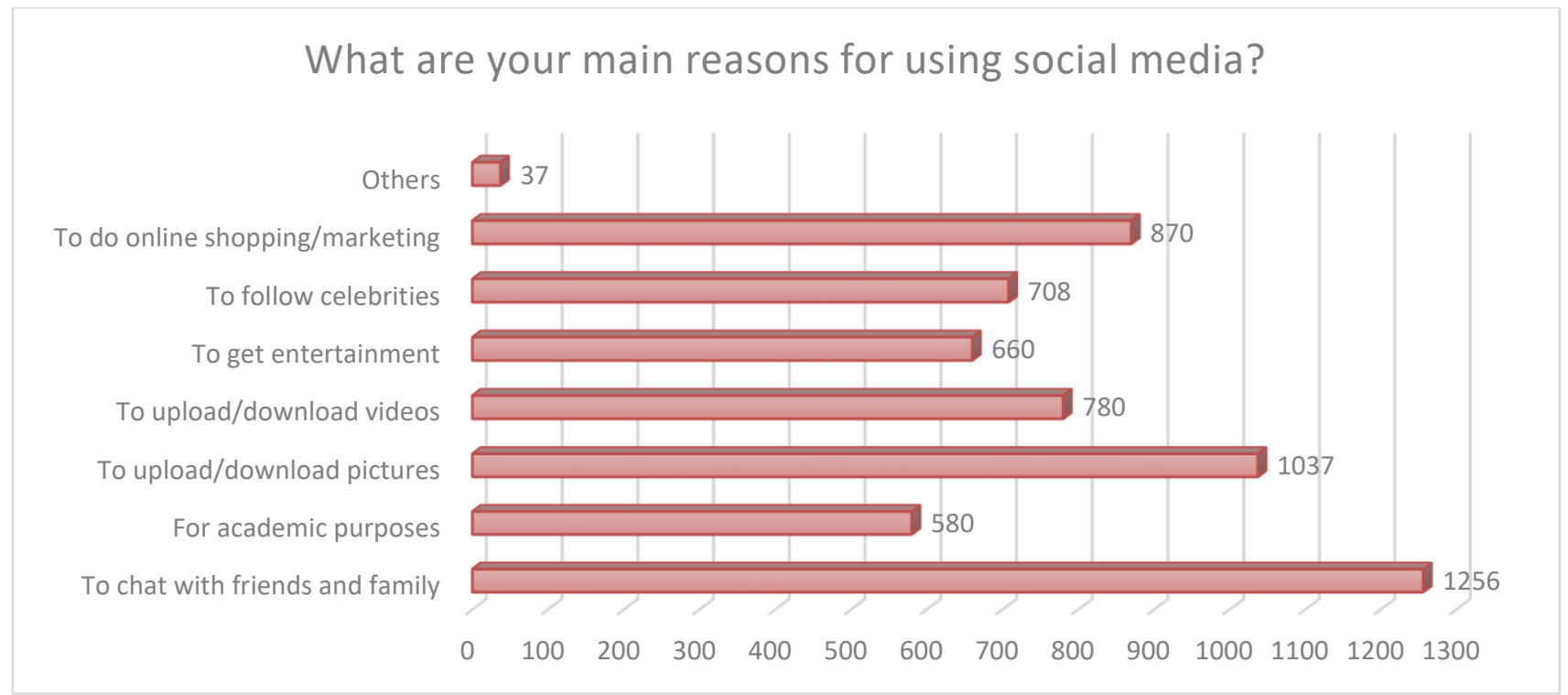

Being a multiple option question, respondents had the opportunity to select many options as they deemed fit. The responses received indicate that 1,256 of the 1,300 (97\%) use he social media to chat with friends and family, to upload/download pictures 1,037 (79.8\%), to do online shopping/marketing 870 (67\%), to upload/download videos 780 (60\%), to follow celebrities 708 $(54.4 \%)$, entertainment purposes $(51 \%)$, for academic purposes $(45 \%)$. 
The fifth chart was concerned with the frequency of reading books:

Chart 5: "How often do you read books?"

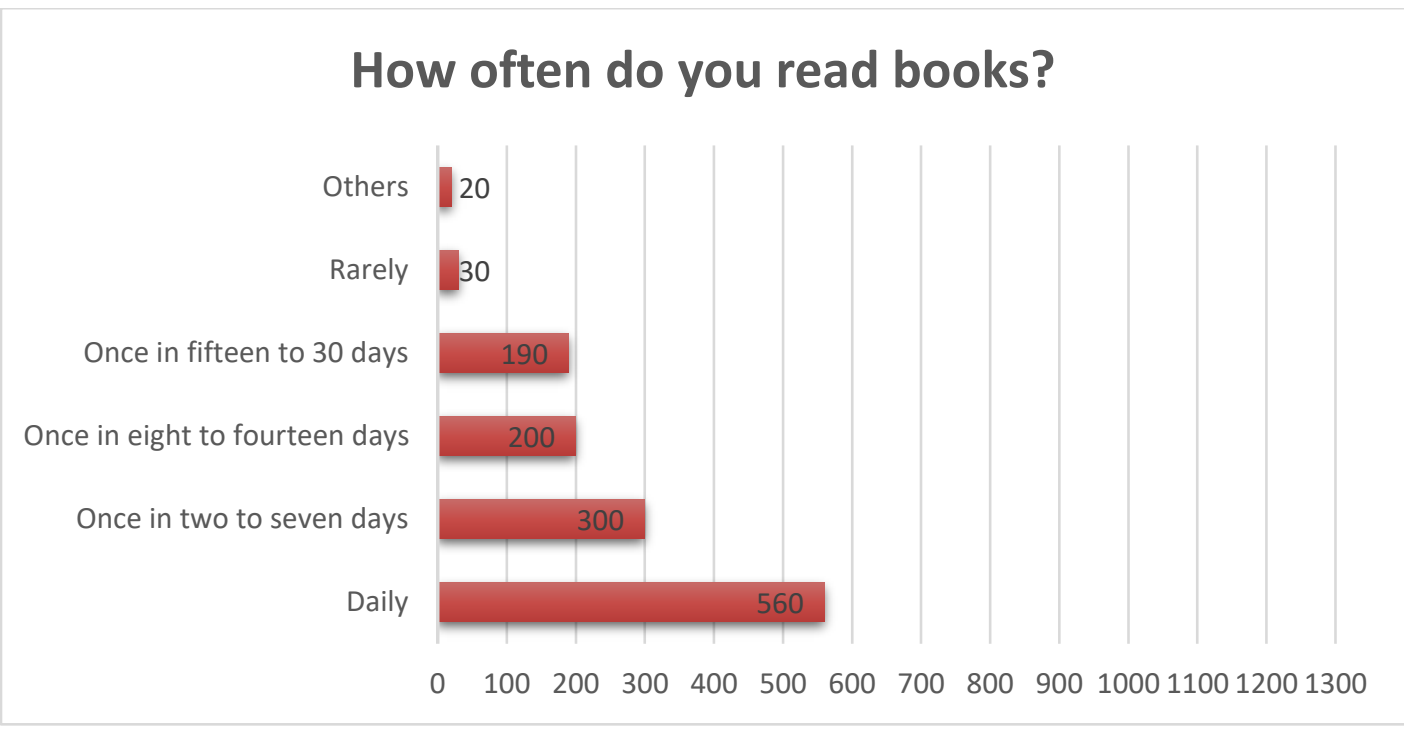

A total of 1300 responses were received, 560 (43\%) of them indicate they read book daily.300 (23\%) read once in two to seven days, 200(15.3\%) read once in eight to fourteen days, 190 $(15 \%)$ read once in fifteen to 30 days, 30 (2.3\%) rarely read books.

The sixth chart considered the reason for reading books:

Chart 6: "What are your major reasons for reading books?"

\section{What are your major reason for reading books?}

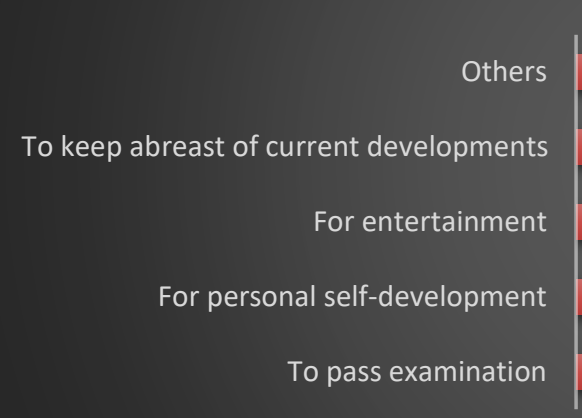


A total of 1300 responses were received, 1025(79\%) of them indicate they read mainly to pass exams, 150(12\%) read for entertainment, 45 (3.4\%) read to keep abreast of current developments, while $28(2.1 \%)$ read for self-development.

The seventh chart considered the frequency of visit to libraries either to read or borrow books:

Chart 7: "How often do you visit your academic or public library to read or borrow books?"

\section{How often do you visit your academic or public library to read or borrow books?}

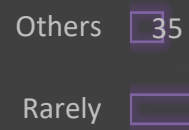

Once in fifteen to 30 days $\quad \square 12$

Once in eight to fourteen days 89

Once in two to seven days 57

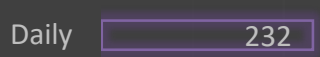

A total of 1,300 responses were received, $875(67.3 \%)$ of them indicate they rarely visit the library.232 (18\%) visit the library daily. 
The eighth chart explored the activities that the respondents engaged in

Chart 8: "Which of the following activities take most of your time during the Lock down to check the spread of Covid-19?"

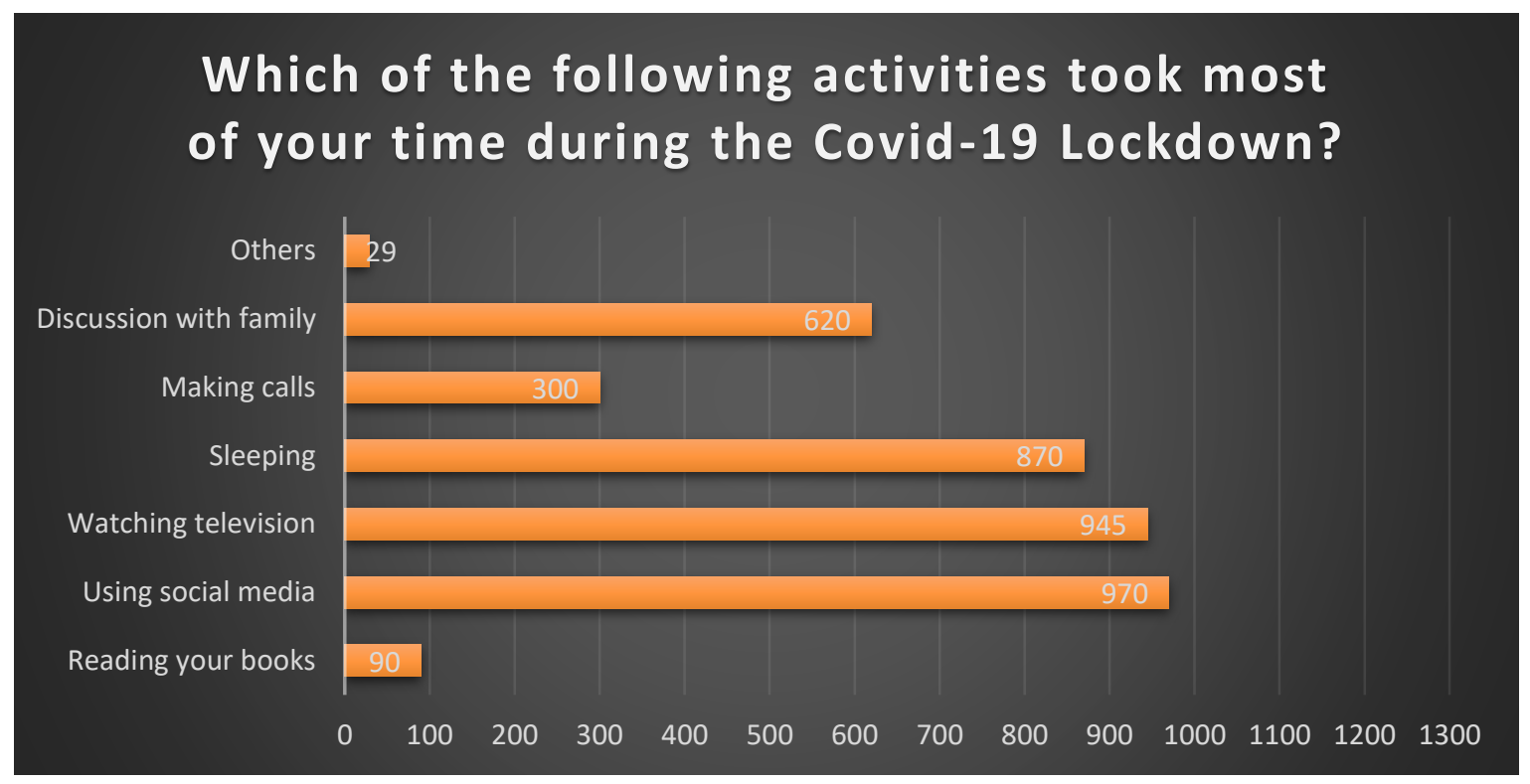

Being a multiple option question, respondents had the opportunity to select many options as they deemed fit. The responses received indicate that 970 (75\%) engaged in social media activities, 945 (73\%) watched television, 870(67\%) engaged in sleeping, 620 (48\%) engaged in discussion with family members, 300 (23\%) engaged in making phone calls, while 90 (7\%) engaged in reading books. 
Chart Nine dealt with activities that give respondents more satisfaction:

Chart 9:"Which of the following activities give you more satisfaction?"

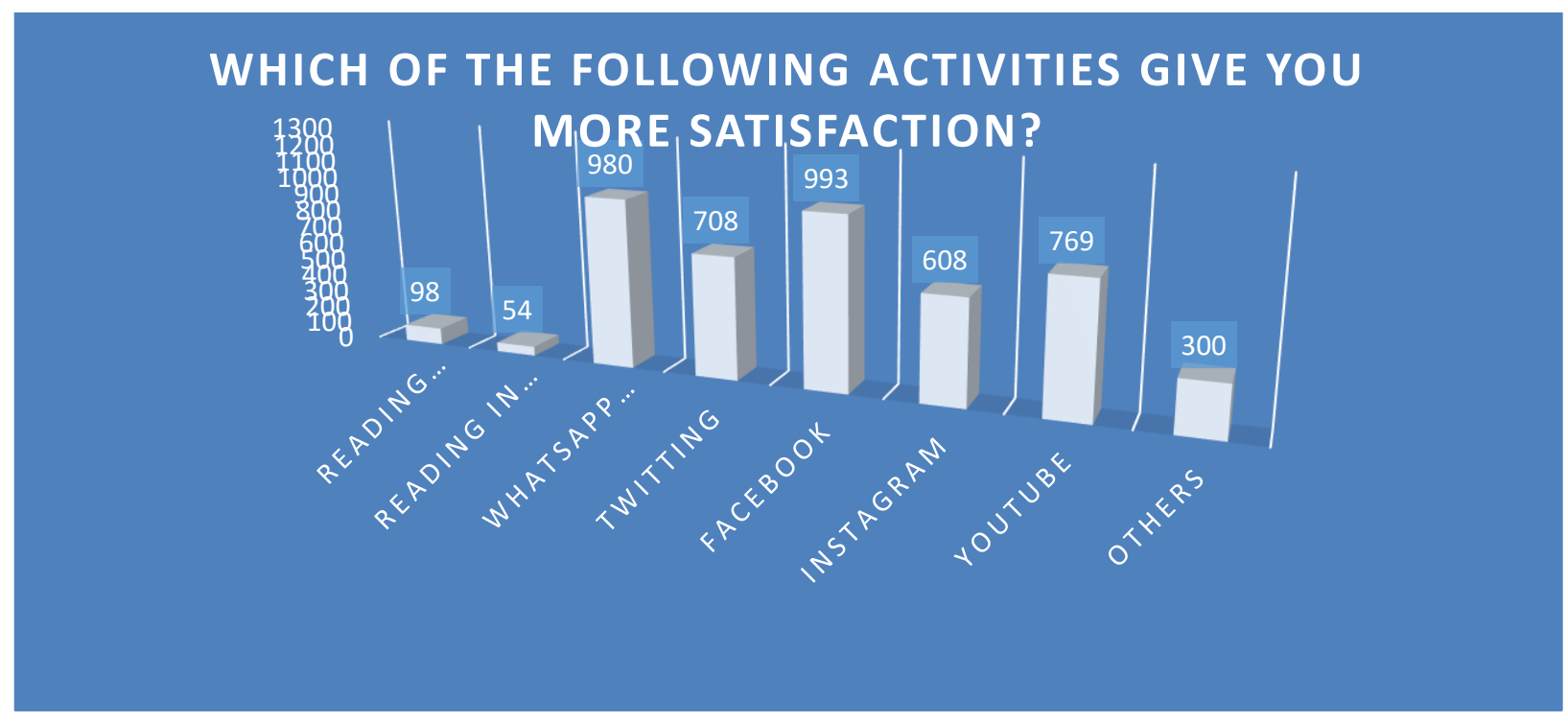

Being a multiple option question, respondents had the opportunity to select many options as they deemed fit. The responses received indicate that 993 (76.3\%) derive satisfaction from Facebook, 980 (75.3\%) indicated WhatsApp Chatting,769 indicated YouTube, 708 Twitter, 608 Instagram, $98(7.5 \%)$ get satisfaction from reading books at home, and $54(4.1 \%)$ get satisfied reading in the library. 
Chart 10 sampled opinion on the level of agreement that social media negates reading habit:

Chart 10: "Do you agree that social media has negative effect on students reading habit?"

\section{DO YOU AGREE THAT SOCIAL MEDIA HAS NEGATIVE EFFECT ON STUDENTS READING HABIT?}

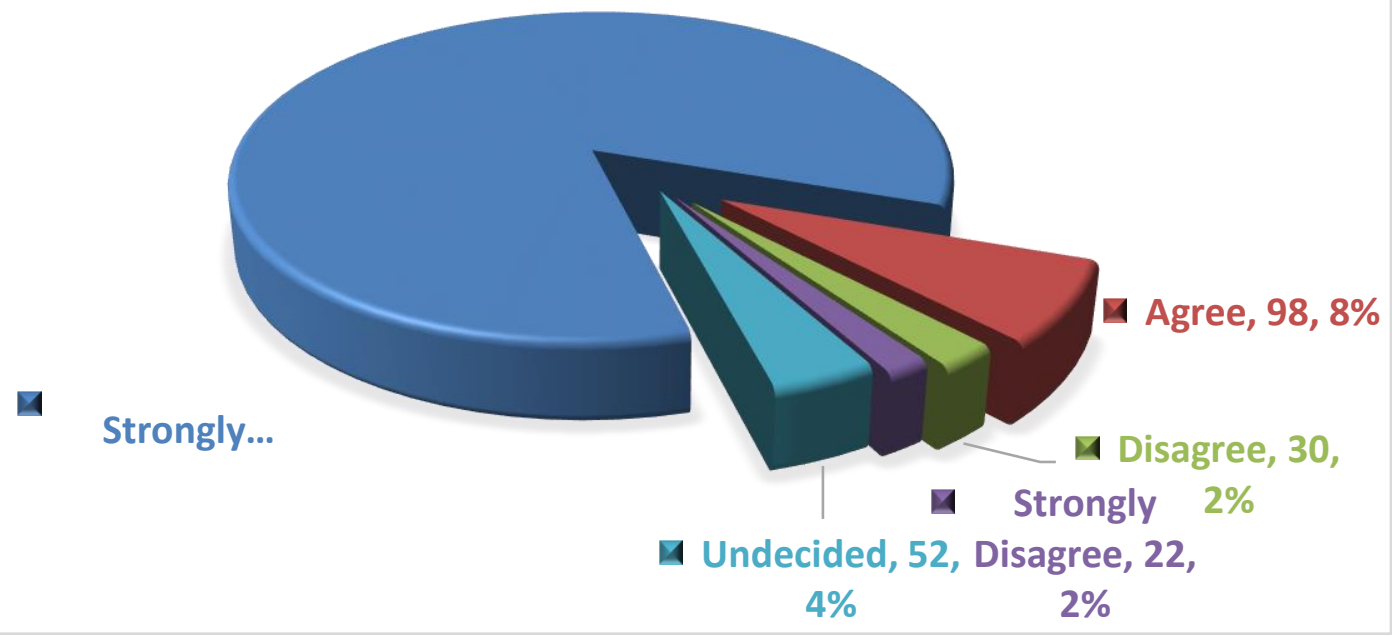

A total of 1,300 (100\%) responses were received. $84.4 \%$ strongly agreed that social media has negative effect on reading habits, $8 \%$ agreed, $4 \%$ are undecided, while $2 \%$ respectively disagreed and strongly disagreed.

\section{Conclusion}

The decline of reading culture among Nigerian students as confirmed in this study has become an issue of increasing concern. The role of social media addiction which has become common in exacerbating the poor reading culture has been established. As the world's economy is moving towards knowledge-based economy, the future of the country is threatened by this ugly development. If nothing drastic is done to tackle the decline headlong, the entire system that make up the Nigerian State including the economic, political, social sub-sets, would also decline as they are all knowledge-driven. 


\section{Recommendations}

To cushion the effect of social media addiction on reading culture among Nigerian students, the following are made:

1. Lecturers should embrace and effectively use social media to teach, give assignments to students, and create reading groups and other learning activities.

2. Bring Your Own Device (BYOD) should be adopted as part of educational technology by Management of Nigerian Higher Education. As such, students should be given access to their institutions' internet services, database and library services through their devices.

3. Nigerian Libraries should make their services and resources accessible to students through their mobile devices.

4. Higher institutions should organize seminars to stir the interests of their students so as to give themselves to reading and researching.

5. Parents should monitor their children reading at home and encourage them to imbibe the habit of life-long readership. Parents should also take their children out to libraries instead of shopping malls or cinemas.

6. Reading should also be encouraged and taught in schools as an essential part of language itself and more reading motivational techniques must be deployed in a more realistic reading culture. 


\section{Reference}

Adesanya, F. (2018). In Bassey, B. (2018). Education stakeholders proffer solutions to poor reading culture. Retrieved from https://www.pulse.ng/communities/student/world-bookday-education-stakeholders-proffer-solutions-to-poor-reading-culture/fbc75xc

Ahmed, A. (2019). Social Media Vs Decline Of Reading Culture. Retrieved from https://thetriumphnews.com/social-media-vs-decline-of-reading-culture/

Akinfenwa, K. (2019). Addressing the Poor Reading Culture in Nigeria. Retrieved from https://www.thisdaylive.com/index.php/2019/03/30/addressing-the-poor-reading-culturein-nigeria/

Bassey, B. (2018). Education stakeholders proffer solutions to poor reading culture. Retrieved from https://www.pulse.ng/communities/student/world-book-day-educationstakeholders-proffer-solutions-to-poor-reading-culture/fbc75xc

Collins, M. and Cheek, E. (1999). Assessing and guiding reading instruction. New York: McGraw Hill.

Fabunmi, F. and Folorunso, O. (2010). Poor Reading Culture: A Barrier to Students' Patronage of Libraries Selected Secondary School in Ado Local Government Area of Ekiti-State, Nigeria. African Research Review, vol 4(2), pp. 450-461.

Iheanacho (2007). Improving the Reading culture for the National Youth: Challenges for the National Library of Nigeria”. JOSSAN vol. 1(1) pg. 36.

Johnson, S. (1999), Strategies to Create Effective Reading Environment for Nigerians. National Reading Week. Paper presented at the Symposium organized by National Library of Nigeria Abuja, February 22-26. pg. 152-179.

Mefor, C. (2011). Reading Culture: the Present And Future of National Development. Retrieved from http://www.cultureindevelopment.nl/News/Discussing_Culture_and_Development/935/Re ading_Culture_-_the_Present_And_Future_of_National_Development 
Ogboko, C. (2018). In Bassey, B. (2018). Education stakeholders proffer solutions to poor reading culture. Retrieved from https://www.pulse.ng/communities/student/world-bookday-education-stakeholders-proffer-solutions-to-poor-reading-culture/fbc75xc

Rubin, D. (2002). Diagnosis and correction in reading and guiding reading instruction. 4th ed. Boston: Allyn and Bacon

Rufa'I, R.A. (2011). In Mefor, C. (2011). Reading Culture: the Present And Future of National Development. Retrieved from http://www.cultureindevelopment.n1/News/Discussing_Culture_and_Development/935/Re ading_Culture_-the_Present_And_Future_of_National_Development

The Pointer Newspaper (n.d.). addressing poor reading culture. Retrieved from https://thepointernewsonline.com/?p=34732 